\title{
SUBJECTIVE EMOTIONS, POLITICAL IMPLICATIONS: THINKING THROUGH TENSIONS AND CONTRADICTIONS IN FEMINIST KNOWLEDGE PRODUCTION ${ }^{1}$
}

\author{
Mia Liinason ${ }^{2}$ and Marta Cuesta ${ }^{3}$ \\ Lund University, Sweden \\ University College Halmstad, Sweden
}

\begin{abstract}
Based on an ongoing research project in which we explore practices, strategies and visions within feminist activism in a Swedish context, this paper emerges from experiences during fieldwork with feminist activist groups. Focusing on tensions and contradictions encountered during fieldwork, this article problematizes the social and emotional dimensions of research. Through a discussion of our interactions with the research participants as subjective relationships and as relationships of power, this article suggests that a closer engagement with the research subject, and with what she can learn from the relationship with the research object, can challenge researchers' implicit assumptions and emotional attachments, contributing to a destabilization of power relations in knowledge production.

Palavras-chave: feminist knowledge production, emotions, research subject, research object, power.

\section{Resumen \\ Emociones sujetivas e implicaciones políticas: reflecciones sobre conflictos y con- tradicciones en la construcción del pensamiento feminista}

Este artículo emerge como parte de un proyecto de investigación, y un trabajo de campo en curso, en donde se exploran visiones, estrategias y prácticas dentro del feminismo activista en Suecia. Poniendo foco en las tensiones y contradicciones desarrolladas durante el trabajo de campo, en este artículo se problematiza acerca de dimensiones a nivel social y emocional conectadas a tópicos de investigación. A traves de una discusión acerca de nuestra participación, dentro del trabajo de campo, desde un punto de vista sujetivo y de poder, en este artículo se sugiere que un acercamiento al sujeto a investigar, y lo que de esa relación se pueda aprender, puede esta prueba implicitamente significar, una contribución a una desestabilización de las relaciones poder, en la producción de conocimientos.
\end{abstract}

Palabras clave: producción de conocimiento feminista, emociones, sujeto de investigación, objeto de investigación, poder.

This article is written within the frames of the project Feminist critique, feminist resistance, feminist hopes (funded by the Swedish Research Council 2012-2015, Dnr 2011-5489). We would like to acknowledge all the research participants for sharing their thoughts, visions and ideas with generosity and care. Previous versions of this article have been presented at conferences and the many insights from participants at those occasions helped us develop our thoughts. We are also grateful for the very useful feedback from the two anonymous peer review readers and thematic section editors.

$2 \quad$ Centre for Gender Studies, Lund University, Sweden. mia.liinason@genus.lu.se 


\begin{abstract}
Resumo
Emoções subjetivas e implicações políticas: reflexões sobre conflitos e contradições na construção de conhecimento feminista

Este artigo emerge de um projeto de investigação em curso que tem como objetivo explorar as visões, estratégias e práticas no seio do ativismo feminista na Suécia. Centrando-se nas tensões e conflitos que emergiram no trabalho de campo, o artigo problematiza as dimensões sociais e emocionais da investigação feminista. Tomamos como ponto de partida uma conceptualização das nossas interações com as/os participantes como relações subjetivas e relações de poder, e sugerimos que uma reflexão mais aprofundada sobre o sujeito de investigação, e sobre o que ela/e pode aprender na relação com o objeto de investigação, permite problematizar os pressupostos implícitos e investimentos emocionais das/os investigadoras/es, contribuindo assim para a desestabilização das relações de poder na produção de conhecimento.
\end{abstract}

Palavras-chave: Produção de conhecimento feminista, emocões, sujeito de investigação, objeto de investigação, poder.

The idea that knowledge production is relational, contextual and always interacting with multiple and asymmetrical power orders is a crucial point of departure in feminist methodology, aiming to develop emancipatory narratives and produce partial, positioned and accountable knowledge (Hill Collins, 2000; hooks, 2000; Bhavnani, 1995; Haraway, 1988; Harding, 1986). Although we agree with the relevance of these contributions, we also feel a need for further methodological reflection on how to deal with the relationship between ourselves as researchers and our research participants in a fruitful way, and how to manage the relations of power implicated in the research process.

Therefore, in this article we focus on tensions and contradictions encountered during fieldwork. Our aim is to problematize the social and emotional dimensions of the research process, guided by the following questions: How can we understand our own implication in the research process, in situations of personal interaction, as well as in terms of wider relationships of power? How do we balance the relationship with the research participants so that we as researchers and as feminists establish trust in our interactions, and act in an accountable way in relation to our participants? And, what is the role of emotions in this context: can we reach a deeper understanding of these complex processes by paying attention to contradictions when subjective desires and collective goals are not in agreement, for example?

We discuss the above questions drawing on an ongoing ethnographic study of practices, strategies and visions within contemporary feminist activism in Sweden. The project follows five feminist activist groups located in three large cities. These groups focus on a variety of issues, among them: anti-racism and anti-sexism in working life and organizations, a queer and anti-capitalist struggle for the development of non-commercial spaces in the city, the development of a feminist, LGBT - and anti-racist network to build alliances, and, to shelter, sup- 
port and collaborate with asylum seekers and improve refugee and migration policies. In the last year, we met these groups once a week, sometimes two or three times per week. The illustrations in this article are based on fieldnotes from a workshop and interviews with members from two of the groups. At these occasions, around 25 activists participated.

Methodologically, we position ourselves as feminists and consider ourselves part of the situations we encounter during the research. This means that we perceive our own interventions in the situations that arise during fieldwork as an integrated part of the material of the study. Using methods that put an emphasis on presence (over time), personal interaction and social dynamics, has made it possible for us to analyse negotiations around issues of power in everyday interactions with the groups (Cuesta, 1997; Mulinari, 1995). Our frequent meetings with these collectives of politically engaged individuals have also enabled us as researchers to take up a position around a variety of feminist issues, through an exchange of knowledge, ideas and experiences. Within the context of knowledge production, feminist scholars describe positionality as a way of breaking a 'blank faced' distance, or neutrality (Frankenberg, 1993; Haraway, 1988). Positionality can be understood as an approach to research, for example in dialogues or interviews, by engaging in conversations through a sincere and deeper exchange of ideas, where «differences in power are (...) openly discussed and acknowledged» (Ryan-Flood and Gill, 2010: 5).

In our research process, positionality has made it possible for us to take responsibility in the interaction with our participants, but it has also, as we discuss in this article, created dilemmas. In the feminist struggle, a large variety of strategies are used by different groups in different contexts to counteract discrimination and injustice. The different political strategies used by the groups that we follow have in some situations been challenging for us as feminists or as researchers, and these challenges have affected us in various ways - both intellectually and emotionally. Initially we found it difficult to understand how to take into account our emotional reactions (negative, or positive, and sometimes contradictory) in the research process. Subsequently though, we found that closer attention to our subjective feelings could actually help us understand the situations we took part in. As Gayle Letherby (2003) emphasizes, the complex relationship between researchers and participants can be taken into account through analyses of emotions as sources of knowledge in the research process, where multiple political identities, social locations and theoretical perspectives interact. In our view, attention to emotions offer a possibility to think through how the different positions taken up in a concrete situation illuminate negotiations and struggles around relations of power, both locally and in a wider social context. This may enable a better understanding of relationality and contextuality in the research process.

Affects, emotions and feelings are interrelated notions with slightly different meanings. In this article, we understand affects as immediate bodily reactions such as warmth, increased pulse etc. - to stimulus. «Bodily-based affects», as Tiina 
Rosenberg (2013: 180) explains, «are the total sum of the events one has experienced in life. Thus, [they are] determined not only by the individual, but also by one's life history and the culture of which we all are a part». Emotions and feelings are understood as affective states. Here, we understand emotions as the conscious awareness of affects, while we understand feelings as subjective representations of emotions. Since we are interested in analysing our respective, and different, subjective partialities and responsibilities in the research process, we focus on primarily the variegated feelings experienced in the situations discussed.

In the first section below, we develop our points of departure. Against the background of the useful feminist criticism of the distant and disembodied researcher, we take an interest in understanding the relationship between the subject and object of research, asking how we can take into account the complex, and also sometimes contradictory subjectivities, power relations and positionalities in the research process, while remaining accountable. The second section discusses tensions and contradictions as they emerged during the research process. The analysis in this section follows an experimental idea in which we deconstruct the dichotomy objectivity/subjectivity. Here, we (Mia and Marta) present and analyse illustrations from a personal view and enter into dialogue with each other's narratives. Finding that our subjective and social positions are contradictory yet collective, the third and final section of this article suggests ways to understand and manage these positions productively. Here, we discuss how attention to subjective emotions and political implications may balance our different subjectivities, and the variegated implications of these for the research process as well as for feminism.

\section{Power relations in research interaction}

Feminist explorations of the research process have, as Róisín Ryan-Flood and Rosalind Gill describe, «transformed understandings of methodology, epistemology, subjectivity and agency in social research» (2010: 2). Highlighting how, among other things, the interactions between researcher and respondent affect the knowledge produced, feminist scholars have developed models for taking embodiment, subjectivity and social location into account (Fonow and Cook, 2005; Hill Collins, 2000; Haraway, 1988; Harding, 1986). Yet, despite the useful feminist criticism of the distant and disembodied researcher, we still found it difficult to understand how we could manage the power relations we were inscribed into and part of. How would we, for example, use Donna Haraway's (1988) notion of situated knowledges ${ }^{4}$ without reducing it to a set of static

According to Haraway (1988), situated knowledges is feminist objectivity. She explains situated knowledges as partial, locatable and critical knowledges. Haraway uses vision as the metaphor for situated knowledges, in which positioning is key, because it implies resonsibility for our actions and practices. 
identity categories or routine-like positioning? And how would we understand Haraway's (1988) suggestion that knowledge objects are created in social interaction? Emerging from these questions, we began to think of the relationship between the subject and object in research and the diverse ways a research object can be placed in a study - as an Other; as an idealized fetish; as a projected phantasy making our desires 'real'. In our ambitions to analytically understand the complex relationship between the subject and object of research, we felt a need for closer engagement with the research object's impact on the research subject. While we agree with feminist understandings of how the research subject and object co-constitute each other (Finlay, 2002; Haraway, 1988), we want to take this understanding one step further and pay attention to how the research object provokes and affects the subject, her perceptions, perspectives and positions. In this understanding, we consider the research object both as a source of knowledge and as a critical interlocutor that challenges our implicit assumptions and emotional attachments. Such a perspective, we believe, can offer useful insights into the research subject's partiality and responsibility in relation to the study.

Several feminist scholars have taken interest in how intersubjective relationships influence research (Letherby, 2003; Finlay, 2002). In order to make power relations in such relationships explicit, feminists have often favoured «processes of critical reflection, or reflexivity» (Ramazanoglu and Holland, 2002: 118). Indeed, in our efforts to reach a deeper understanding of the interplay between ourselves as research subjects and our research participants, reflexivity has been an important tool. Reflexivity, however, has also been criticized by feminists, mainly because of the risks attached to reflexivity as «navel-gazing» (Finlay, 2002: 541). Therefore, and with the intention to focus on how the object of research deconstructs/reconstructs the subject in interaction, we have tried to strike a balance between an analysis of our subjective reactions and the implications of these for the specific issue in focus, as well as for the feminist project at large. Here, our launch point away from the research subjects as «particular knowing selves» (Ramazanoglu and Holland, 2005: 105) to a focus on the interplay between research subjects and objects serves to illuminate the multi-faceted and also sometimes contradictory routes of a research process, in which the interdependences and implicatedness of us as subjects implies a destabilization of the research subject, as well as of the research process, as coherent and rational.

Our mixed roles as researchers and feminists created challenges that became particularly manifest in some research situations. For many of our participants, it was important that we shared their values and experiences. If not, they could quickly become suspicious, dismissive or negative - attitudes that we could easily understand considering our own experiences in feminist activist groups. To gain access, we had to establish trust. Trust is established in different ways. It does not always, or only, rely on the existence of a common base - shared points of references, interrelated political views and/or ideological positions. Trust can also emerge from other forms of trustworthiness, based on, for exam- 
ple, intersubjective relationships between the researcher and the participants, building on rapport (mutuality in attention, feelings, body language etc.). Furthermore, a researcher is often seen as a trustworthy person, because of the researcher's skills, knowledge and position. In the case of our groups, however, academic qualifications did not automatically generate trust. As a matter of fact, many of our research participants held suspicions towards academics because they found them too distanced from people's everyday lives and experiences, and because they feared that academics would de-politicize or de-radicalize their issues. On the other hand, experiences of feminist activism were highly respected by most of our participants, and although the tension between academy and activism was persistent in some groups more than others, it meant that we had to balance our different roles as academics, activists and feminists in order to establish trust in relation to many of the groups.

The complexities we encountered were played out through personal statements and emotions in the interaction with the groups. The workshops and meetings we took part in, as well as the interviews carried out, subsequently became situations in which we interacted much like anyone else in the group - we took up ideological positions, we disagreed with, or supported, suggestions. Still, our ambitions to act like others in the groups also created dilemmas, mainly because the purpose of our presence differed from that of other participants. Primarily, we wanted to have access to the groups to collect material for our research. On the one hand, we did not want to make too forceful an impact on the group discussions, because that could risk jeopardizing the plurality of knowledge in the group. On the other hand, if we were too passive or persistent, we faced the risk of losing access to the group. And thirdly, as feminists ourselves, we sometimes felt the urge to interact, take responsibility in the situation. This multi-faceted character of our presence occurred in relation to all groups involved in our research, but raised specific challenges in some groups.

\section{Positionality and contradictions}

In this section, we present and analyse selected illustrations collected as «field notes» from meetings with two different groups. The methods in use were participant observation and interviews. The first illustration describes the tensions created through the incoherence in positionality between us as researchers and the group in question. We had earned the trust from the group, but it was limited because of ideological disagreements. The second illustration describes contradictions established by reciprocal good intentions/mutual desire between ourselves and the activists. Trust was given but challenged, which complicated the interview situation. 


\section{The colours of trust}

When we initially asked the group InterAkt ${ }^{5}$ if we could follow their activities as a part of our project, they were suspicious, towards us as researchers as well as the project. They had many questions and wanted to regulate our presence and participation. We were asked to send an official request to the board and after some weeks, one member gave us the following response over e-mail:

The board has decided and you are welcome to follow our work. I want to underline, though, that when you are going to be present at events aimed for and by racialized people, this also pertains to you, if you want to participate.

InterAkt is an anti-racist and anti-sexist community that fights for structural change in society, with a focus on working life and organizations. From the outset, we understood that trust from this group would entail hard work on our part, due to their understanding of the notion 'racialized', a central base for strategies used in their political struggle. According to their definitions, a 'racialized' person is a person who is at 'risk of experiencing racism' and includes: 1) people born abroad, 2) non-white adopted, 3) people born in Sweden but with one or two parents born abroad.

Mia:

We interpreted their agreement to our participation as semi-conditional which meant that I (Mia), as a white person with parents born in Sweden, was not welcome to these particular events but my co-researcher (Marta), who is from Latin America, would be welcome. When we took part in an Anti-racist feminist workshop arranged by the group, it became clear that my co-researcher and I had a different understanding of the notion 'racialized' than the group, and that we did not agree with their ideas about political strategy, in which they push for affirmative action when it comes to race and sex but disregard other categories, such as class, for example. During the workshop, one participant explained why the group supported the gender equality minister, a black right-wing politician, known for her ethnocentric and dual-sex-normative ${ }^{6}$ gender equality policy ${ }^{7}$ :

All names of groups and individuals are changed so as to secure anonymity for the individuals and respect the ethical guidelines for this project.

6 By dual-sex normative, we refer to an understanding of gender that is restricted to include only heterosexual and cisgendered men and women.

7 This minister, Nyamko Sabuni, stirred up vivid discussions among the feminist and gender equal-friendly community in Sweden because she did not want to call herself a 'feminist' which was seen as a strong political statement from a gender equality minister in a Swedish context. In winter 2013, a few months after our meeting with the group, this minister resigned from her post. 
It is a process in two steps. First, there are white old men. We want to place racialized women there instead, even if they are incompetent. Only the fact that they are there will make a change. People have different experiences. And then, finally, we will we be able to locate competent women there.

My co-researcher Marta asked for an explanation of this, saying: «but maybe, not all immigrants have a radical political view. Why give everybody power, if they cannot accommodate it in a way that expands justice?» At this juncture, the position taken up by Marta created a situation where the regular distribution of authority was challenged. Some participants became curious and wanted to learn from us, while others became hostile. Marta insisted: «Do you mean that, for example, the gender equality minister is ok, because she is black?» The tensions rose, but we continued to focus on these issues because we wanted a deeper understanding of want the group meant by anti-racism. Nadya, one member, asked: «How far can we stretch our solidarity? What will the consequences be?» Marta argued that: «To give power to a racialized person could also be dangerous, very similar to giving power to a white person (...)». Nadya continued: "If I feel comfortable in one context, I know that the coalition is not broad enough». Here, Nadya was pointing to the importance in a feminist group, of inviting people with different standpoints and visions. My co-researcher insisted: "You know, she [the gender equality minister] is against the use of the veil, she is for legislation against the veil! I don't think that she takes part in developing a more equal society. Do you think so?» Nadya affirmed: «Good question. There's no simple answer to it», and with that, the exchange was closed and the workshop moved to other issues.

Afterwards, Marta and I talked about the fact that we had earned the trust from this group by respecting their foundations and limits. My feelings on being excluded from participating in meetings for racialized people were rather ambivalent. At first, I reacted positively because I found it important to agree, seeing that as a white person I seldom experience exclusions on the basis of my race. My second feeling was that I became upset over their essentializing definition, limiting racialization only to black people - wasn't I experiencing racialization in that very moment, and if so, shouldn't I also be included in their activities? Yet, even though such an analysis might have been correct within a one-dimensional logic (simple exclusion/inclusion), I also agreed with the group's standpoint, because these dilemmas must always be contextualized in broader relations of power and cultural dominance (Yuval-Davis and Anthias, 1992). Still though, it was difficult for me to simply accept their position. How could I manage my dis/agreement with their politics of representation, without acting in accordance with precisely this politics myself? Their message interpellated me. Did I have to confirm this interpellation and act on it? My contradictory feelings, in which I both respected their viewpoints and felt upset about them, left me feeling trapped, because both threatened to make me into someone that I felt I was not. 
However, analysing my contradictory feelings led me to a different location than first anticipated. Thinking about how all this located me as a subject in the struggle, I examined my own aims and motives in feminism. As Clare Hemmings discusses (2012), the feminist struggle is based on feelings: of dissonance, anger or discomfort. If something feels wrong, one might feel compelled to change it. Our variegated subjective feelings of discrimination and injustice are therefore necessary in the feminist struggle. But, in order for the struggle not to be fragmented into identity projects or monopolized by existing homogeneities, these subjective feelings need to be transformed into political agendas, actions and aims - a shift in focus that Hemmings calls «affective solidarity» (2012: 147). In thinking through this, I realized that I wanted to support a feminist struggle in which there is a plurality of voices and bodies. These reflections were not based on an essentialized understanding of race, nor on feelings of white guilt or offense. Instead, my contradictory feelings forced me to understand my position in relation to the political dimensions of our relationship. In such a relationship, the group and I were present as subjects, with all our feelings of shame, anger, or hopes for change, but we needed to politicize these feelings, in order for the struggle to have a wider reach than our own respective subjective existences, whatever they might be. I realized that my own feelings were relevant only in so far as they pushed me to my own limit, which in this case was my understanding of the feminist struggle. The only way I could act in this politicized relationship, therefore, was to submit to the categorizations of me as a white, privileged person - even though that meant that, for example, I was excluded from participating in some activities despite my subjective commitment against such a fixed view of identities and categorizations - because I wanted to support feminism as a plural movement. There are moments where particular struggles need some subjects, experiences and knowledges more than others. Feminism in Sweden, for example, is still dominated by white women, and if I wanted to support the struggle for a more plural feminist movement, side-lining my feelings was a step in that direction.

Marta:

After the workshop, I (Marta) felt very uncomfortable and wanted to cut the links with the group. I reacted strongly to their glorification of ethnicity, in terms of inverted racism. I felt offended, being a racialized citizen myself. As time went on, however, I calmed down. I began to reflect on my feelings from a more contextual point of view and realized that our participation could be a contribution to the group on the level of consciousness-raising, by shedding light on sensitive dilemmas and complex questions. This was a conciliatory feeling, but it also engendered dilemmas, seeing that the idea of consciousness-raising implied that we as researchers were in the position of the knower - an implication that also involved an unequal power relationship between us as researchers and the participants - which is a view we did not agree with and that we had struggled to 
avoid during the research process. In the meeting, we avoided taking on an authoritarian role, but asked questions and pointed to consequences, so as to highlight the contradictions. However ambivalent the feelings afterwards were, hopefully our participation during the workshop contributed in a similar way as everyone else at the workshop, to develop feminist knowledge production further. We started a discussion on what anti-racist feminism stands for and challenged the consensus in the group around an issue at the core of their political program, which might lead to a more nuanced understanding of what anti-racist feminism stands for. At the same time we respected the boundaries and ideopolitical positions in the group.

\section{The limits of dialogues}

The group FemKoll allowed us from the very beginning to integrate their narrative as a part of our research project, and we were openly welcomed to their meetings, events, and actions. The contacts with this group were established both on a formal and an informal basis. This group is a feminist, LGBTQ-, anti-capitalist, anti-racist and leftist community, organized in the form of a network, gathering both private persons and organizations, and their aim is to offer possibilities for the development of coalitions between organizations and individuals. The following illustration relates to a group interview with pioneers of the group.

\section{Marta:}

I met the members of the group at the main door to the headquarters of the network. The person with the key to the door was late and we decided to go to a café around the corner. As we walked, we talked loosely about the research project, and about me. During this walk, one group member said: «You and your colleague must feel very lucky. I can just imagine me doing feminist activism and writing about feminism. It couldn't be better. Are you happy?» «Yes I am!» I confirmed, «and we are very proud of this responsibility». What I did not say, was that I feel very privileged to work on this project. On many occasions it gives me legitimacy as an academic, and I could not think of a better research project than this. My feelings about the pending interview were also comfortable: «Trust is already established», I thought. Not only because many of us already knew each other - we had met in teaching rooms and at different events in the city - but also because I knew that we shared a similar feminist vision. At the same time, I also worried about the fact that many of the participants in the group had been my students and this could make our relationship more complicated. I persuaded myself to think positively: «Maybe that'll make everyone comfortable and relaxed. I'm sure that the meeting will result in deeper understandings of feminism and feminist organization».

I introduced myself, and a round of presentations was given. The group 
included children and friends (those present were not all active members of the network), in line with the policy of this group, which is to include everyone who comes and wants to participate, independent of their circumstances. I then described what I thought of the dialogues that were going to be developed:

"Your accounts will help us to construct ideas about feminism today, independent of the different standpoints each one of you have. You can be open and express your vision, feelings and criticism».

«But we have a common standpoint in the group!» someone exclaims. Another person affirms: «When we met a couple of years ago and decided to create a network, we wanted to strengthen feminism through activism because we believe that's urgent in Sweden today».

«Yes!» a third person adds, «I'm also one of the founders (...). From the very beginning we knew that it would be a hard task. Feminism today is divided and we saw the need to establish a platform, a network. It involves hard work, very hard. (...)

One participant explains: «We started this network as feminists who wanted to struggle for feminism. We come from different organisations, but as a network, we can interact without limits».

«But what is feminism for you, as a group?» I ask, and continue: «Do you want to link the feminist struggle with other struggles, for example with anti-racism, or sexual rights?»

«Yes, of course. We stand for an intersectional view», one of the pioneers responds.

«Very good», I say, but insist: «But I cannot see any closer links with an international struggle in your activities.»

At this moment I felt that my participation was too persistent, despite the fact that nobody reacted towards my statement and all seemed relaxed. I, however, started to feel uncomfortable. I did not want us to enter into a theoretical discussion. I apologized and explained that the idea with this interview was to construct a narrative from their point of view. I was afraid that my intervention could influence their narrative, make them silent or insecure. My possible role as an authority figure could create feelings of insufficiency among them in relation to feminist issues. I asked the group what they thought would be the best way to continue the dialogue.

«NO, no, your questions are very interesting and contribute very much to our understanding of the commitment in the group» one person affirmed.

«I agree, we have discussed that we need to think more about our program in relation to the world outside of Sweden», another participant clarifies.

«All right, all right!» I say, «Of course, we can continue by doing more interactive dialogues. Pero ustedes siguen con el comando [But I still want you to take the command]», I spontaneously say in my mother tongue and everybody laughs in a friendly way, including those who do not understand Spanish. 
We decided to take a break, and when we restarted the interview, the participants engaged more deeply with the issues discussed as my role suddenly became clearer. The dialogues developed around the history of the network, intersectionality and the impact of anti-racism in feminist struggles.

From the start, I had been confident that this interview would be relaxed and comfortable. However, and perhaps precisely because I felt relaxed with this group, I forgot my initial plan not to ask polemic questions. The contradictions created by my behaviour could very well have created distrust among the participants. Instead, however, they paved the way for deeper engagement. Through my polemic, the participants' goals became more nuanced and situated in terms of temporality («in the beginning of the network...»; «at present...»; «in the future...»). Maybe it worked because of an unconditional trust in me among many of these participants, or because of strong feminist identifications, however ambivalent those identifications may be (Butler, 1992). Or maybe it worked because by withdrawing my polemic question, I refrained from taking up the position of authority, showing that I was interested in constructing a narrative from their point of view. This encounter, however, also engaged me emotionally, as it often does when I meet this group. When I return home after activities, I often feel exhausted. On many occasions, I interact actively with the group, but that also makes me more vulnerable. The group accepts and includes me, which is a fruitful basis for the creation of emancipatory knowledge, but at the same time, I feel a heavy responsibility, in relation to the group and to the wider feminist struggle. I want this group and their struggle to be successful, and my dual positions as a feminist and a researcher make me strongly invested in the relationships and interactions with the group.

Mia:

I did not take part in this interview, but when I talked with Marta about it afterwards I could see that there existed a mutual desire between Marta as a feminist researcher, and the members of FemKoll, all of whom have strong feelings about their shared projects and feminist visions. Both Marta and the activists were keen to listen to each other's stories, ideas and suggestions, confirming each other's participation. The conversation is open, the atmosphere smooth and relaxed. However, and although Marta describes the interview situation as comfortable, characterized by trust and safety, there is also a tacit presence of insecurity around how to deal with authority, unity and disunity in this group. As one participant in the interview describes, the purpose of starting the network in the first place was to create a shared feminist platform, precisely because of the many «divisions» in feminism today. Interestingly, it is not the agenda that unites this group, but its organizational form: a network to establish coalitions with feminists and other political groups. The common standpoint that the participants refer to is a wish to strengthen feminism through the work that feminism does. Although I myself sympathize strongly with these points of departures, there are 
constructions of unity and inclusion in this group that can be treacherous for the transformative work they want to achieve. A single interview with one of the pioneers, Nelly, points to the difficulties created through precisely these expectations of coherence in the group. During this interview, she explained:

From the start, I could feel that it was quite nice that we abandoned the exchange of experiences, but perhaps it's important to have these? ... it was as if we focused on feminist strategies rather quickly, and skipped conversations about personal experiences. (---) When we met, we had a lot of earlier experiences, and now, we wanted to act. I have been talking with friends, 'what do I do with this feeling, with the world and with life?'. I am not interested in working with that, but I am interested in ... like in assuming that we have the same experiences and then just do ... like just act out from these, in one way.

As her explanation illuminates, the endless discussions around never ceasing experiences of injustice, created restlessness and a desire to act. But despite the explicit wish to expand the network, so that people with diverse experiences and knowledges take part, this is a difficult challenge for the group. Nelly continues:

Representation, what does that mean? And [what does it mean] in such a homogenous group like the collective is? It's here I think it's dangerous to be so academically knowledgeable, and know theories because one has read these words and because it's possible to talk away about this. I understand that I am a... privileged person. I can analyse and it sounds good that I can say, see, you are a privileged person. But in practical life, something more needs to be done. I think the most difficult issue is to work sincerely with representation, that we have a width [in representation]. Academic knowledge can threaten representation and multiplicity as well, because one unites around words that everyone understands and concepts we all know and a consensus around what feminism is, so that not everyone can take part.

As Nelly emphasizes, the low presence of an exchange of experiences creates the attractive force of the network. Here, people gather because they have a desire to act and to do things instead of 'just' talking about them. At the same time, she also reflects on the implicit assumptions and lack of discussions as creating exclusions and consensus, and that the homogeneity among the participants risks narrowing the reach of the network. The feelings of inclusion and safety that Marta experienced during the group interview may point to precisely this homogeneity. She fits perfectly with the group - she is a feminist academic and knows all the concepts. She belongs to the Latina diaspora community in this city, which some of the founding members of the group also belong to, a connection that also was made manifest through her use of Spanish during the interview situation. Through the shift in language, Marta moves closer to the members in the group who understand Spanish, but also further away from those 
who do not understand or do not belong to the community she addresses through the use of the language, or who do not understand the academic concepts used. The feelings of exhaustion, and of heavy responsibility, that she experiences after meeting with this group are emotional responses to the contradictions established through feelings of safety and agreement during their interactions, aware that the comfortable feelings of inclusion and unity are built upon a politically dangerous construction of 'us' and 'them'.

\section{Located narrative}

As our interactions with the groups show, our subjective roles and social positions are contradictory and collective (Ahmed, 1997). In these contexts, we assume our positions as subjects, with all our feelings of desire, anger, shame, or hopes for change. But although our subjective feelings of discrimination and injustice are necessary for feminist struggle, these subjective feelings, as we have argued, need to be transformed into political agendas, actions and aims (Hemmings, 2012), in order for the struggle not to be fragmented into identity projects or monopolized by consensus-based inclusion.

In our interactions with the groups, we as researchers were taking up - and were positioned in - different relationships, which were also relationships of power. In the first illustration, we negotiated with the group InterAkt around their understanding of 'racialized' and their political agenda. At the farthest end of these negotiations lay the question of trust: how could we establish trust and act as feminists accountably? In the second illustration, Marta enjoyed a sense of security and unity while meeting FemKoll. However, the safe feelings shaped through a shared feminist vision and sense of safe space, created contradictory feelings of trust and vulnerability, energy and exhaustion, of identifying with a strong feminist community while at the same time experiencing feelings of heavy responsibility in relation to the group. Paying attention to the social dimensions of these tensions and contradictions forced us to examine our views on the political aspects of our relationship with the activists and on the aims of feminist struggle, where issues of ideology and the construction of the community inevitably become entangled with the way feminism is practiced, irrespective of whether this is made explicit in the specific struggle ${ }^{8}$.

When we took part in workshops and meetings as researchers, we experienced a multi-faceted relationship to the communities we visited. We felt that we had to negotiate our dual roles as researchers and feminists and we often questioned ourselves if we made the right decision when we held back our arguments in order to listen to the group, or when we expressed our disagreements to stir the consensus. In terms of «competing convictions and desires», Karen Throsby

\footnotetext{
${ }^{8}$ Today, we continue to follow both groups and meet their members on a regular basis.
} 
and Debra Gimlin (2010: 108) discuss similar dilemmas in relation to research experiences where their subjective desires and feminist goals were not in agreement. They suggest that these dilemmas are not to be seen as resolvable problems, but rather as complex resources to «think reflexively about (...) - as sociologists, and as feminists» (2010: 109). Indeed, we agree on the usefulness of paying careful attention to dilemmas like this, to refine and deepen our understanding of the complexities involved. The differences between ourselves (as researchers) and the activists involved power and antagonisms, but the different reasons why we decided to keep quiet, or the different ways in which the groups responded to our arguments, were understood as part of the material we collected. The understanding of our relationship as politicized made it possible for us to treat both the groups and our interactions with them as part of our research. To include ourselves and the reactions that our participation engendered made the research messy, but made it more difficult for us to treat our participants as idealized fetishes, or as boosting mirrors for our own desires. This attention to the feelings produced in the research process involved contradictions, instabilities, and insecurities, but it also challenged our subjective departures and emotional attachments and allowed us to better understand the entanglements between ourselves and what we study.

\section{Bibliography}

Ahmed, Sara (1997), «“It's a sun-tan isn't it?" Autobiography as an identificatory practice», in Heidi Safia Mirza (ed.) Black British Feminism, London, Routledge, pp. 153$-167$.

Bhavnani, Kum Kum (1994), «Tracing the Contours: Feminist Research and Feminist Objectivity», in Haleh Afshar and Mary Maynard (eds.), The Dynamics of «Race» and Gender: Some Feminist Interventions, London, Taylor \& Francis, pp. 26-40.

Butler, Judith (1992), «Contingent Foundations: Feminism and the Question of 'Postmodernism'», in Judith Butler and Joan W. Scott (eds.), Feminists theorize the Political, London, Routledge, pp. 3-21.

Cuesta, Marta (1997), Flowers to the ocean: a study of everyday practices, rituals and identity in Candomblé, Studentlitteratur, Lund.

Finlay, Linda (2002), «"Outing" the researcher: The Provenance, Process and Practice of Reflexivity", Qualitative health research, 12, 4, pp. 531-545.

Fonow, Mary Margaret, Cook, Judith A. (2005), «Feminist methodology: New Applications in the Academy and Public Policy», Signs, 30, 4, pp. 2212-2236.

Frankenberg, Ruth (1993), White women, race matters: the social construction of whiteness, London, Routledge.

Harding, Sandra (1986), The science question in feminism, Ithaca, Cornell University Press.

Haraway, Donna (1988), «Situated Knowledges: The Science Question in Feminism and the Privilege of Partial Perspective», Feminist Studies, 14, 3, pp. 575-599.

Hemmings, Clare (2012), «Affective solidarity: Feminist reflexivity and political transformation», Feminist Theory, 13, 2, pp. 147-161. 
Hill Collins, Patricia (2000), Black feminist thought: knowledge, consciousness, and the politics of empowerment, New York, Routledge.

Hooks, Bell (2000), Feminism is for everybody: Passionate politics, Cambridge, South End Press.

Letherby, Gayle (2003), Feminist research in theory and practice, Philadelphia, Open University Press.

Mulinari, Diana (1995), Motherwork and politics in revolutionary Nicaragua: «Huellas de Dolor y Esperanza», Lund, Bokbox.

Ramazanoglu, Caroline and Holland, Janet (2002), Feminist methodology. Challenges and choices, London, SAGE.

Rosenberg, Tiina (2013), «The soundtrack of revolution. Memory, affect and the power of protest songs», Culture Unbound: Journal of Current Cultural Research, 5, pp. 175-188.

Ryan-Flood, Róisín, Gill, Rosalind (2010), «Introduction», in Róisín Ryan-Flood and Rosalind Gill (eds.), Secrecy and silence in the research process. Feminist reflections, London, Routledge, pp. 1-11.

Throsby, Karen, Gimlin, Debra (2010), «Critiquing thinness and wanting to be thin», in Róisín Ryan-Flood and Rosalind Gill (eds.), Secrecy and silence in the research process. Feminist reflections, London, Routledge, pp. 105-116.

Yuval-Davis, Nira, Anthias, Floya (1992), Racialized Boundaries, London, Routledge.

Mia Liinason and Marta Cuesta work in a joint research project on contemporary feminist activism in Sweden, funded by the Swedish Research Council. Mia is a post-doctoral scholar at the Department for Gender Studies, Lund University, with an interest in feminist movements, feminist theory and feminist methodology. Marta Cuesta is assistant professor in sociology at the Section for health and society, University College Halmstad, with an interest for feminist pedagogy and knowledge production.

Mia Liinason

Centre for Gender Studies, Lund University, Box 117, 22100 LUND, Sweden. mia.liinason@genus.lu.se

Marta Cuesta

School of Social and Health Sciences, University College Halmstad, PO Box 823, SE-301 18 HALMSTAD, Sweden. Marta.Cuesta@hh.se

Artigo recebido em 10 de setembro de 2013 e aceite para publicação em 27 de janeiro de 2014. 